\title{
Assessment of mountain slope instability in the Lish River basin of Eastern Darjeeling Himalaya using frequency ratio model (FRM)
}

\author{
Biplab Mandal $^{1} \cdot$ Sujit Mandal $^{1}$
}

Received: 29 April 2016/ Accepted: 4 June 2016/Published online: 29 June 2016

(C) Springer International Publishing Switzerland 2016

\begin{abstract}
Landslides are the most destructive natural hazards that undermine the economic and cultural development in Darjeeling Himalaya. To prepare landslide susceptibility map of the Lish River basin of Eastern Darjeeling Himalaya frequency ratio model (FRM) was applied based on remote sensing and GIS tools and an integration of ten landslide triggering parameters or factors like Geomorphology, lithology, slope angle, slope aspect, slope curvature, drainage density, NDVI, Relative Relief, land use and land cover (LULC) and soli map were made. The frequency ratio model (FRM) was used to derive class frequency ratio or class weight incorporating both pixels with and without landslides and to determine the relative importance of individual classes. All the data layers were prepared in consultation with SOI Topo-sheet (78B/9), Google earth image, Landsat 8 OLI (operational land imager), GDEM (Global Digital Elevation Model) image with the help of Arc View and ARC GIS Software (10.1). A Weighted linear combination model was performed to combine frequency ratio/class rating values and to determine the landslide susceptibility index (LSI) value on GIS software tools. Greater the value of 'LSI', higher is the propensity of landslide susceptibility over the space. Then, the Lish River basin was classified into six landslide susceptibility zones, i.e., very low, low, moderate, moderately high, high and very high considering the ranges of LSI.
\end{abstract}

Sujit Mandal

mandalsujit2009@gmail.com

Biplab Mandal

biplab.malda001@gmail.com

1 Department of Geography, University of Gour Banga, Malda 732101, West Bengal, India
Keywords Landslide $\cdot$ Darjeeling Himalaya Frequency ratio model (FRM) $\cdot$ RS and GIS

\section{Introduction}

The frequent occurrences of landslides in Darjeeling Himalaya causes havoc damages to natural resources as well as human infrastructures. The destructions and damages of settlements, communication lines, tea garden area, and agricultural land are the common phenomena in Darjeeling Himalaya which triggers to environmental disasters. The changes in the land use character in the mountain slope are caused due to these environmental hazards. The upper surface of the Darjeeling Himalaya is composed of heavily disintegrated and decomposed materials. The accumulation of the materials and its increasing weight as a result of drainage concentration and saturation caused due to continuous rainfall for few days basically invites slope failure in the southern escarpment slope of Darjeeling Himalaya. The devastating landslip of June, 2015 and destruction of lives and properties in Darjeeling caused as a result of few day continuous heavy rainfall. Landslides are simply defined as the movement of dislodged rocks, debris or earth materials down a slope including a broad range of motions whereby falling, sliding and flowing under the influence of gravity. In most of the cases, the landslide is the critical mechanism of erosional processes and in such condition landslide is inevitable and necessary part of the natural landscape process system. Although the occurrences of landslide hazards and its impact on human society cannot be prevented fully by analyzing the slope stability condition, but the better understanding of geo-technical attributes of the soil can contribute to greater knowledge and understanding about the spatial distribution of slope 

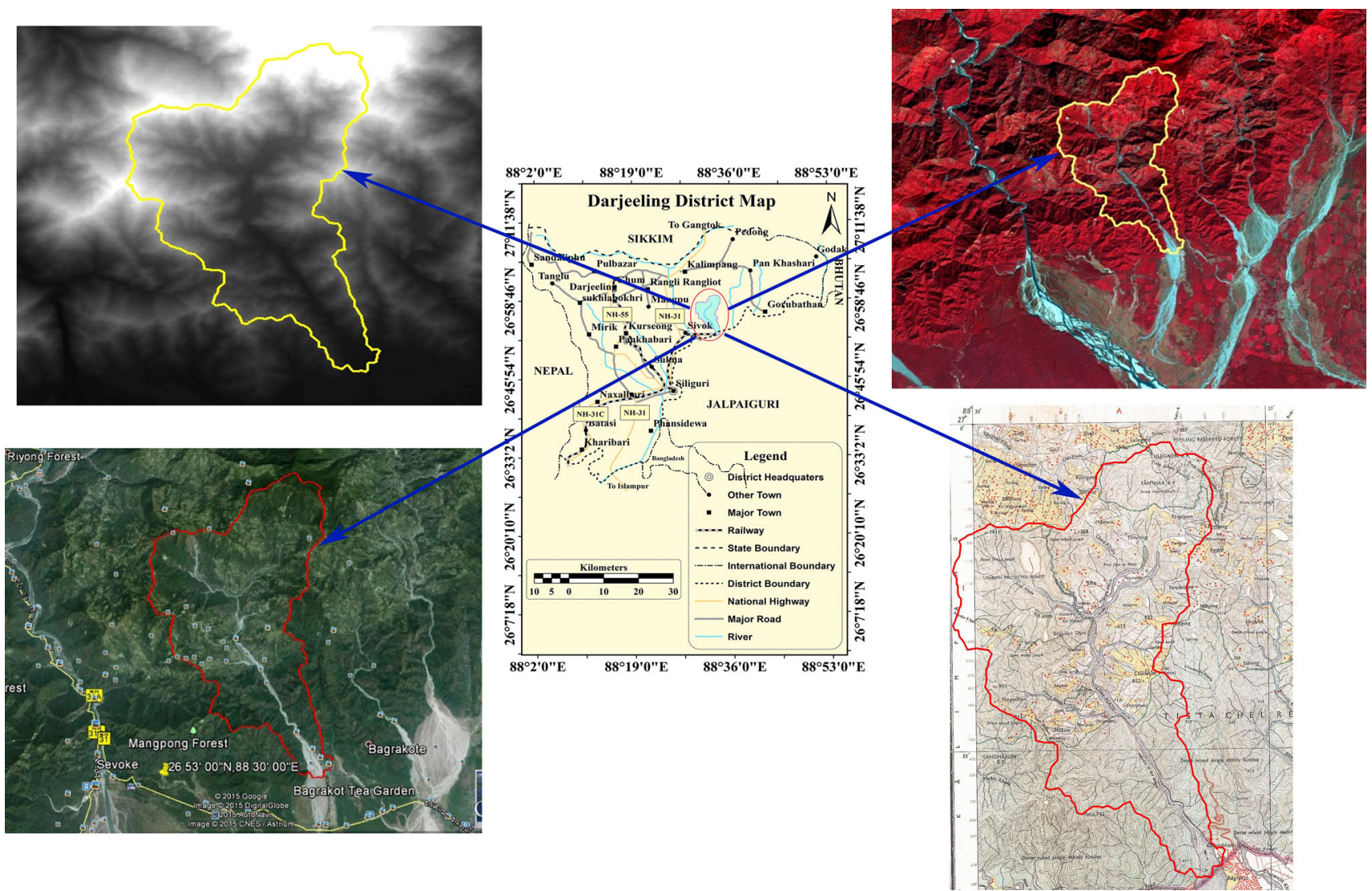

Fig. 1 Location map of the study area (Lish River basin in Darjeeling district)

instability which are very much essential for land use planning. Landslides are the result of two interacting sets of forces; the precondition factors, naturally induced which govern the stability conditions of slopes, and the preparatory and triggering factors, induced either by natural factors or by human intervention. Landslide analysis is mainly done by assessing Susceptibility, Hazard and Risk (Einstein 1988). Landslide is one of the most threatening disasters to human life all over the world. Every year, we may read the report about significant human losses caused by landslide (Lee 2004). Therefore, it is important to do some research why landslide is so frequent and what in order to prevent it. Many scholars concentrated on the trigger factor of landslide; with different results (Lee et al. 2012; Bui et al. 2012).

RS and GIS based landslide hazard zonation/assessment or landslide susceptibility mapping approach had been studied by Anbalagan (1992), Varnes and IAEG (1984), Sarkar et al. (1995), Borga et al. (1998), Dhakal et al. (2000), Muthu and Petrou (2007), Kamp et al. (2008), Caiyan and Jianping (2009), Ahmed et al. (2014) and Ghorai et al. (2015). Basu (1990) have studied impact of landslides on fluvial processes in the Lish basin of the Darjeeling Himalayas. Rowbotham and Dudycha (1998), Donati and Turrini (2002), Lee and Choi (2003), Lee et al.
(2004), Lee and Pradhan (2006, 2007), Pradhan (2010a, b, c), Sarkar and Kanungo (2004), Yalcin (2008), Pandey et al. (2008), Nithya and Prasanna (2010), and Pradhan et al. (2010) have studied and applied the probabilistic model for landslide susceptibility and risk evaluation. Guzzetti et al. (1999), Pardeshi et al. (2013) summarized many landslide hazard evaluation studies. Jibson et al. (2000); and Zhou et al. (2002) applied the probabilistic models for landslide risk and hazard analysis. Atkinson and Massari (1998) introduced the logistic regression model for landslide hazard mapping. Landslide hazard evaluation by using fuzzy logic, and artificial neural network models were being used in the various literatures of Gokceoglu et al. (2000), Pistocchi et al. (2002), Lee et al. (2003, 2004), Pradhan and Lee (2010). Landslide susceptibility mapping using either multivariate or bivariate statistical approach analyzes the historical link between landslide controlling factors and the distribution of landslides (Guzzetti et al. 1999). Erener and Uzgeun (2008) have done their work landslide hazard mapping using regression models versus weight rating models. Besides, there are also a lot of model in landslide susceptibility mapping, such as frequency ratio, artificial neural network, decision tree, weights of evidence, fuzzy logic (Bagherzadeh and Mansouri Daneshvar 2012; Ilanloo 2011; Poudyal et al. 2010; Pourghasemi et al. 2012; 
Table 1 Sources of the data layers of the study area

\begin{tabular}{lll}
\hline Data layers & Data types & Sources of data \\
\hline Slope & Pixel based data & Aster GDEM (Global Digital Elevation Model) \\
Slope aspect & Pixel based data & Aster GDEM \\
Slope curvature & Pixel based data & Aster GDEM \\
Relative relief & Pixel based data & Aster GDEM \\
Drainage density & Pixel based data & Aster GDEM \\
Lithology & $\begin{array}{l}\text { Polygon coverage } \\
\text { data }\end{array}$ & NATMO (National Atlas and Thematic Mapping Organisation) \\
Geomorphology & $\begin{array}{c}\text { Polygon coverage } \\
\text { data }\end{array}$ & NATMO \\
Soil & $\begin{array}{l}\text { Polygon coverage } \\
\text { data }\end{array}$ & NATMO \\
Land use/cover & $\begin{array}{c}\text { Pixel based data } \\
\text { NDVI }\end{array}$ & $\begin{array}{c}\text { LANDSAT 8 OLI (operational land imager) but matched Google Earth image and SOI Toposheet } \\
\text { Landslide }\end{array}$ \\
inventory & $\begin{array}{c}\text { Polygon coverage } \\
\text { data }\end{array}$ & Topographical sheet 78 B/9, Survey of India(Scale 1:50,000), Google Earth image and field survey \\
\hline
\end{tabular}

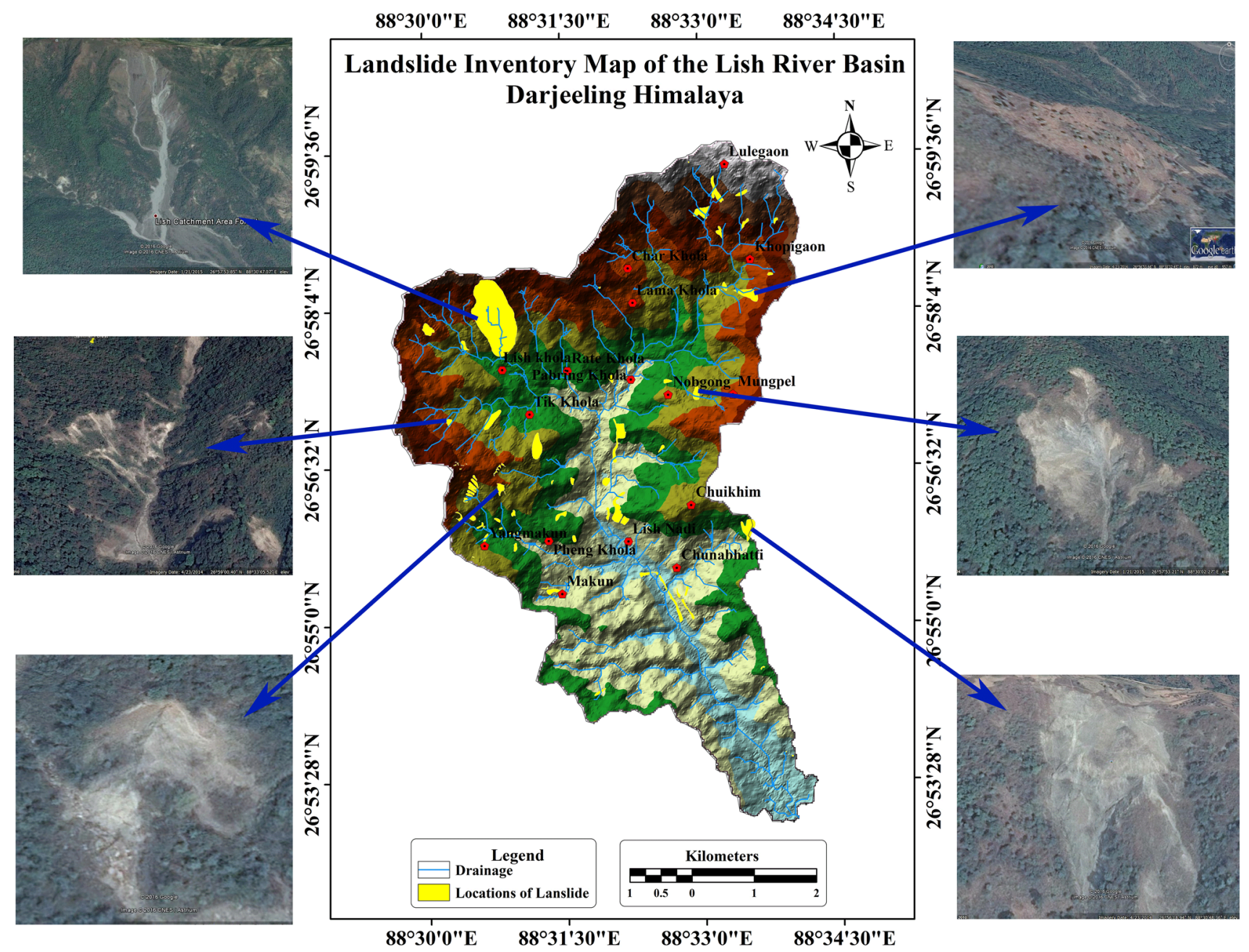

Fig. 2 Landslide inventory map of the Lish River basin 


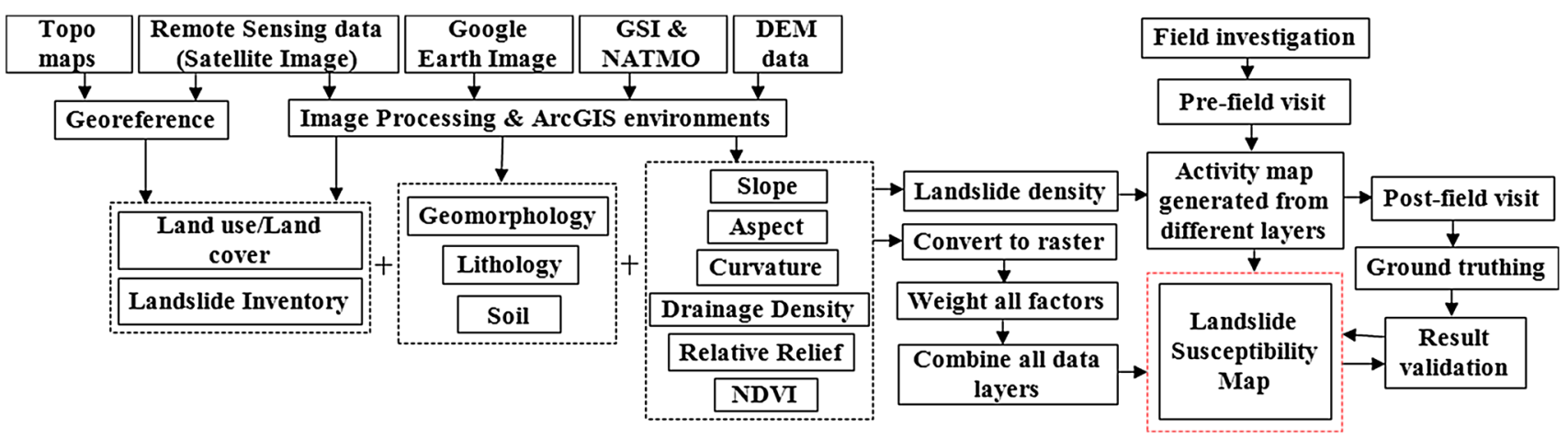

Fig. 3 Methodology flow chart of the study area

Tsai et al. 2013). Komac (2006), Mandal and Maiti (2011) applied to prepare a landslide susceptibility model using analytical hierarchy process. Lee and Sambath (2006), Lee and Pradhan (2007) opined that frequency ratio model provides a correlation between the historical slide locations and various influencing factors under consideration. Intarawichian and Dasananda (2011) applied frequency ratio model to analyze slope instability and ascribed the model as a popular quantitative method.

In the present study, frequency ratio (FR) model was applied to prepare landslide susceptibility map of the Lish River basin of the Eastern Darjeeling Himalaya. This approach is related with the historical landslide events and their areal coverage. Lish River basin, covering a geographical/catchment area $51.72 \mathrm{~km}^{2}$ is a sub basin of Tista river system which is located mainly Eastern Darjeeling Himalaya (Fig. 1). It is enclosed between $26^{\circ} 52^{\prime} 30^{\prime \prime} \mathrm{N}$ to $27^{\circ} 00^{\prime} 00^{\prime \prime} \mathrm{N}$ latitudes and $88^{\circ} 30^{\prime} 00^{\prime \prime} \mathrm{E}$ to $88^{\circ} 34^{\prime} 30^{\prime \prime} \mathrm{E}$ longitudes. The Lish River originating from Lalegoan $\left(26^{\circ} 59^{\prime} \mathrm{N}\right.$ and $88^{\circ} 33^{\prime} \mathrm{E}$ ) at the altitude of $1820 \mathrm{~m}$ traverses a distance of about $21.20 \mathrm{~km}$ to join the mighty river Tista at Shaugoan $\left(26^{\circ} 49^{\prime} \mathrm{N}\right.$ and $\left.88^{\circ} 33^{\prime} \mathrm{E}\right)$. On the way it receives at least 75 tributaries; important among them are the Chun-Khola, Tikkhola, Phang-Khola, Lish-Nadi, Turung-Khola, PabringKhola, Lama-Khola and the Rato-Khola, Char-Khola, etc. The highest and lowest elevations of this basin are 1870 and $166 \mathrm{~m}$, respectively. In the Lish River basin, landslides and floods are the most significant natural problems that undermine the economic and cultural development. Records since 1929 show a sharp acceleration in the rate of devastating slide occurrences (total no. 135 covering an area of $1.5 \mathrm{~km}^{2}$ ) along with lesser slips leading to great loss of life and heavy damage to land and property. The situation has deteriorated further in recent times, the last two decades having witnessed the worst landslides on hill-slopes (total no. 64 covering an area of $4.52 \mathrm{~km}^{2}$ ). It becomes clear that the nature of weak, young set of rocks, predominance of monsoonal climate with high intensity and long duration rainfall and steep mountain escarpment slope are supposed to be the

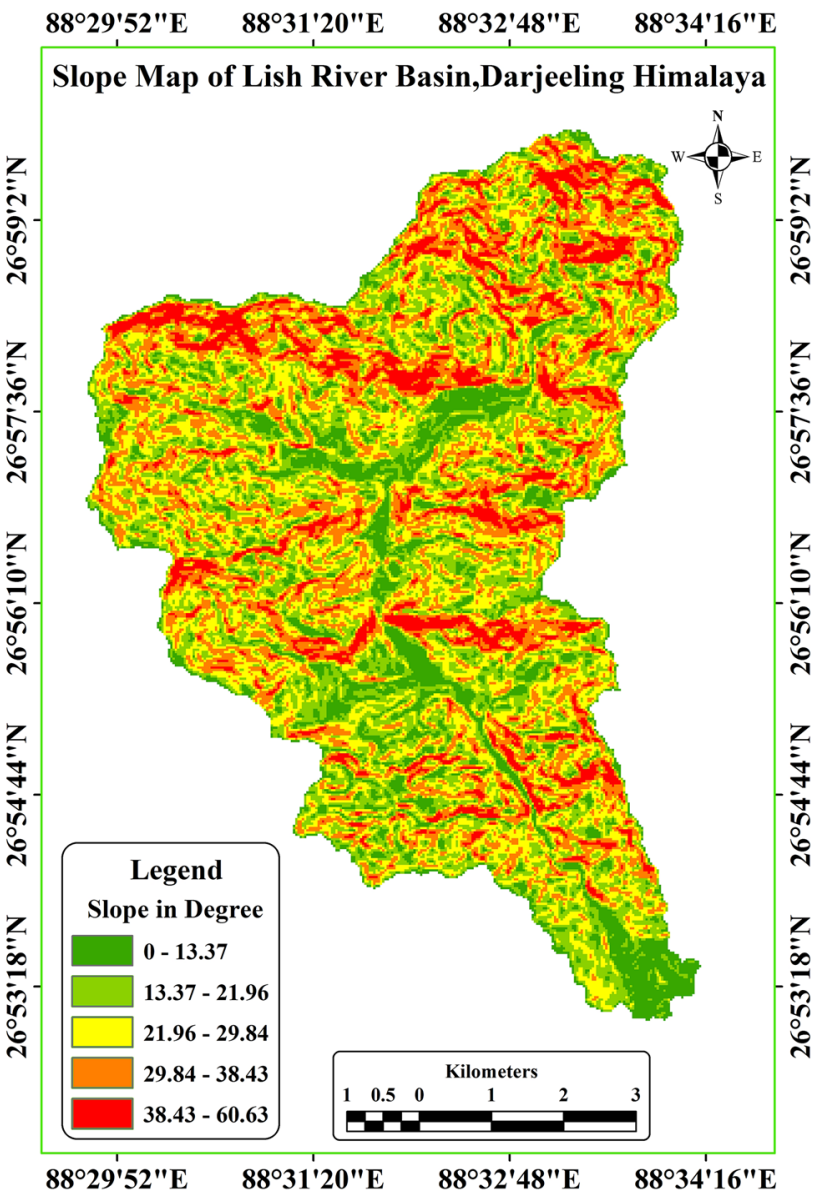

Fig. 4 Slope map of the Lish River basin

major problems associated with landslide in the study area in Darjeeling Himalayan region.

\section{Materials and methods}

The thematic data layers of all the landslide inducing factors were integrated to prepare landslide susceptibility map using a weighted linear combination model on GIS environments. 
Table 2 Class frequency ratio/class rating value Source: estimated by authors

\begin{tabular}{|c|c|c|c|c|c|c|c|}
\hline Classes & $\begin{array}{l}\text { Number of } \\
\text { pixels }\left(F_{1}\right)\end{array}$ & $\begin{array}{l}\text { Number of } \\
\text { pixels in } \%\end{array}$ & $\begin{array}{l}\text { Number of landslide } \\
\text { occurrence pixels }\left(\mathrm{F}_{2}\right)\end{array}$ & $\begin{array}{l}\text { Number of landslide } \\
\text { occurrences pixels in } \%\end{array}$ & $\begin{array}{l}\text { Frequency } \\
\text { ratio in } \%\end{array}$ & $\begin{array}{l}\text { Class } \\
\text { weight }\end{array}$ & $\begin{array}{l}\text { Factor } \\
\text { weight }\end{array}$ \\
\hline \multicolumn{8}{|c|}{ Slope gradient (in degree) } \\
\hline $0-13.37$ & 8916 & 14.63 & 112 & 7.56 & 0.52 & 10.32 & 15 \\
\hline $13.37-21.69$ & 14,612 & 23.97 & 298 & 20.10 & 0.84 & 16.66 & \\
\hline $21.96-29.84$ & 17,122 & 28.09 & 464 & 31.31 & 1.11 & 22.03 & \\
\hline $29.84-38.43$ & 13,827 & 22.68 & 382 & 25.78 & 1.14 & 22.62 & \\
\hline $38.43-60.63$ & 6477 & 10.63 & 226 & 15.25 & 1.43 & 28.37 & \\
\hline \multicolumn{8}{|c|}{ Slope aspect (direction of slope) } \\
\hline Flat $(-1)$ & 5498 & 9.02 & 81 & 5.47 & 0.61 & 6.43 & 05 \\
\hline North (0-22.5) & 6351 & 10.42 & 58 & 3.91 & 0.09 & 0.95 & \\
\hline $\begin{array}{l}\text { North-east } \\
(22.5-67.5)\end{array}$ & 5834 & 9.57 & 98 & 6.61 & 0.69 & 7.27 & \\
\hline East $(67.5-112.5)$ & 6675 & 10.95 & 233 & 15.72 & 1.44 & 15.17 & \\
\hline $\begin{array}{l}\text { South-east } \\
\quad(112.5-157.5)\end{array}$ & 7819 & 12.83 & 170 & 11.46 & 0.89 & 9.38 & \\
\hline $\begin{array}{l}\text { South } \\
\quad(157.5-202.5)\end{array}$ & 7859 & 12.89 & 235 & 15.86 & 1.23 & 12.96 & \\
\hline $\begin{array}{l}\text { South-west } \\
\quad(202.5-247.5)\end{array}$ & 7285 & 11.95 & 286 & 19.30 & 1.62 & 17.07 & \\
\hline $\begin{array}{l}\text { West } \\
\qquad(247.5-292.5)\end{array}$ & 4456 & 7.31 & 120 & 8.10 & 1.11 & 11.70 & \\
\hline $\begin{array}{l}\text { North-west } \\
(292.5-337.5)\end{array}$ & 4485 & 7.36 & 116 & 7.83 & 1.06 & 11.17 & \\
\hline $\begin{array}{l}\text { North } \\
\quad(337.5-360)\end{array}$ & 4692 & 7.70 & 85 & 5.74 & 0.75 & 7.90 & \\
\hline \multicolumn{8}{|c|}{ Slope curvature (positive, negative and zero) } \\
\hline Concave & 27,664 & 45.39 & 707 & 47.71 & 1.05 & 39.33 & 10 \\
\hline Flat & 1639 & 2.69 & 26 & 1.75 & 0.65 & 24.34 & \\
\hline Convex & 31,651 & 51.92 & 749 & 50.54 & 0.97 & 36.33 & \\
\hline \multicolumn{8}{|l|}{ Relative relief (m) } \\
\hline $64.48-225.18$ & 764 & 1.25 & 0 & 0 & 0 & 0 & 08 \\
\hline $225.18-332.31$ & 6416 & 10.53 & 76 & 5.13 & 0.49 & 14.29 & \\
\hline $332.31-399.86$ & 20,453 & 33.55 & 675 & 45.55 & 1.36 & 39.65 & \\
\hline $399.86-465.07$ & 21,943 & 36.00 & 606 & 40.69 & 1.13 & 32.94 & \\
\hline $465.07-658.07$ & 11,378 & 18.67 & 125 & 8.43 & 0.45 & 13.12 & \\
\hline \multicolumn{8}{|c|}{ Lithology (geological composition) } \\
\hline $\begin{array}{l}\text { Sandstone } \\
\text { shale/clay }\end{array}$ & 14,579 & 23.92 & 108 & 7.29 & 0.30 & 13.64 & 20 \\
\hline $\begin{array}{l}\text { Slate, schists, } \\
\text { quartzite }\end{array}$ & 36,129 & 59.27 & 1257 & 84.82 & 1.43 & 65 & \\
\hline $\begin{array}{l}\text { Unclassified, } \\
\text { crystallines }\end{array}$ & 10,246 & 16.81 & 117 & 7.89 & 0.47 & 21.36 & \\
\hline \multicolumn{8}{|c|}{ Geomorphology (morphological composition) } \\
\hline Folded ridge & 19,179 & 31.46 & 914 & 61.67 & 1.96 & 70.50 & 15 \\
\hline $\begin{array}{l}\text { Highly dissected } \\
\text { hill slope }\end{array}$ & 30,947 & 50.77 & 543 & 36.64 & 0.72 & 25.90 & \\
\hline $\begin{array}{l}\text { Piedmont fan } \\
\text { plain }\end{array}$ & 10,828 & 17.77 & 25 & 1.69 & 0.10 & 3.60 & \\
\hline
\end{tabular}


Table 2 continued

\begin{tabular}{|c|c|c|c|c|c|c|c|}
\hline Classes & $\begin{array}{l}\text { Number of } \\
\text { pixels }\left(F_{1}\right)\end{array}$ & $\begin{array}{l}\text { Number of } \\
\text { pixels in \% }\end{array}$ & $\begin{array}{l}\text { Number of landslide } \\
\text { occurrence pixels }\left(\mathrm{F}_{2}\right)\end{array}$ & $\begin{array}{l}\text { Number of landslide } \\
\text { occurrences pixels in \% }\end{array}$ & $\begin{array}{l}\text { Frequency } \\
\text { ratio in } \%\end{array}$ & $\begin{array}{l}\text { Class } \\
\text { weight }\end{array}$ & $\begin{array}{l}\text { Factor } \\
\text { weight }\end{array}$ \\
\hline \multicolumn{8}{|c|}{ Land use and land cover (LULC) } \\
\hline Agricultural land & 1279 & 2.10 & 28 & 1.89 & 0.9 & 15.74 & \multirow[t]{6}{*}{07} \\
\hline Fallow land & 340 & 0.56 & 5 & 0.34 & 0.61 & 10.66 & \\
\hline $\begin{array}{l}\text { Dense mixed } \\
\text { jungle }\end{array}$ & 45,613 & 74.83 & 1109 & 74.83 & 1 & 17.48 & \\
\hline $\begin{array}{l}\text { Open mixed } \\
\text { jungle }\end{array}$ & 6765 & 11.10 & 112 & 8.23 & 0.74 & 12.94 & \\
\hline River & 3173 & 5.20 & 51 & 3.44 & 0.66 & 11.54 & \\
\hline Settlement & 3784 & 6.21 & 167 & 11.27 & 1.81 & 31.64 & \\
\hline \multicolumn{8}{|l|}{ Soil } \\
\hline W002 & 34,632 & 56.82 & 1082 & 73.01 & 1.28 & 49.61 & \multirow[t]{3}{*}{10} \\
\hline W004 & 10,950 & 17.96 & 215 & 14.51 & 0.81 & 31.40 & \\
\hline W008 & 15,372 & 25.22 & 185 & 12.48 & 0.49 & 18.99 & \\
\hline \multicolumn{8}{|c|}{ Normalised differential value index (NDVI) } \\
\hline $0.014-0.121$ & 7013 & 11.51 & 198 & 13.36 & 1.16 & 23.06 & \multirow[t]{5}{*}{05} \\
\hline $0.121-0.200$ & 11,790 & 19.34 & 287 & 19.37 & 1.00 & 19.88 & \\
\hline $0.200-0.270$ & 14,307 & 23.47 & 322 & 21.73 & 0.93 & 18.49 & \\
\hline $0.270-0.340$ & 16,209 & 26.59 & 439 & 29.62 & 1.11 & 22.07 & \\
\hline $0.340-0.500$ & 11,635 & 19.09 & 236 & 15.92 & 0.83 & 16.50 & \\
\hline \multicolumn{8}{|c|}{ Drainage density (length of drainage, $\mathrm{km} / \mathrm{km}^{2}$ ) } \\
\hline $\begin{array}{l}\text { 0-396.43 (very } \\
\text { low) }\end{array}$ & 13,858 & 22.74 & 363 & 24.49 & 1.08 & 20.07 & \multirow[t]{5}{*}{05} \\
\hline $\begin{array}{l}396.43-729.44 \\
\quad(\text { low) }\end{array}$ & 20,896 & 34.28 & 456 & 30.77 & 0.90 & 16.73 & \\
\hline $\begin{array}{l}\text { 729.44-1094.17 } \\
\text { (moderate) }\end{array}$ & 16,664 & 27.34 & 363 & 24.49 & 0.90 & 16.73 & \\
\hline $\begin{array}{l}\text { 1094.17-2077.33 } \\
\text { (high) }\end{array}$ & 8227 & 13.50 & 262 & 17.68 & 1.31 & 24.35 & \\
\hline $\begin{array}{l}\text { 2077.33-4043.67 } \\
\text { (very high) }\end{array}$ & 1309 & 2.15 & 38 & 2.56 & 1.19 & 22.12 & \\
\hline
\end{tabular}

In the present study, Frequency Ration Model was applied to obtain prioritized class rating value (PCRV) for all the landslide triggering factors considered in the study. A weighted linear combination model on GIS environments was performed to estimate landslide susceptibility index value (LSIV) for each pixel and a suitable classification technique was incorporated to prepare the landslide susceptibility map of the Lish River basin. The Lish River basin is covered by $78 \mathrm{~B} / 9$ Toposheet with scale 1:50,000 of Survey of India (SOI). The corresponding Toposheet was registered on Universal Transverse Mercator (UTM) projection system with World Geodetic Survey (WGS) 84 datum considering nearest neighbour resampling method. The data used in the present study are Satellite image LANDSAT 8 OLI (operational land imager), Aster GDEM $(30 \times 30 \mathrm{~m}$ resolution with dated June 2015), Google Earth Image (September, 2015), Geological Map (Geological Survey of India, East Kolkata) and Topographical Map (78B/9, Survey of India). Using Aster GDEM, Slope map, aspect map, curvature map, relative relief, elevation and drainage density were prepared. Soil map, lithological map, and geomorphological map were collected from NATMO (National Atlas and Thematic Mapping Organisation). Land use/cover mapis derived evaluating LANDSAT 8 OLI image data using supervised classification technique and following maximum likelihood method. Drainage network map was prepared from SOI Toposheet (78B/9) with the help of ARC GIS software (10.1) (Table 1).

Landslide Distribution Map/inventory map was carved out to determine landslide affected area (\%) and frequency of landslide for each class of the landslide inducing factors/factors maps evaluating SOI Toposheet, Google Earth Image and intensive field investigation with GPS. Then, it was digitized and transformed into raster value domain in ARC GIS environments. All the landslide triggering factor maps were incorporated with the prepared landslide inventory map to derive frequency ratio value for each pixel (Figs. 2, 3). 


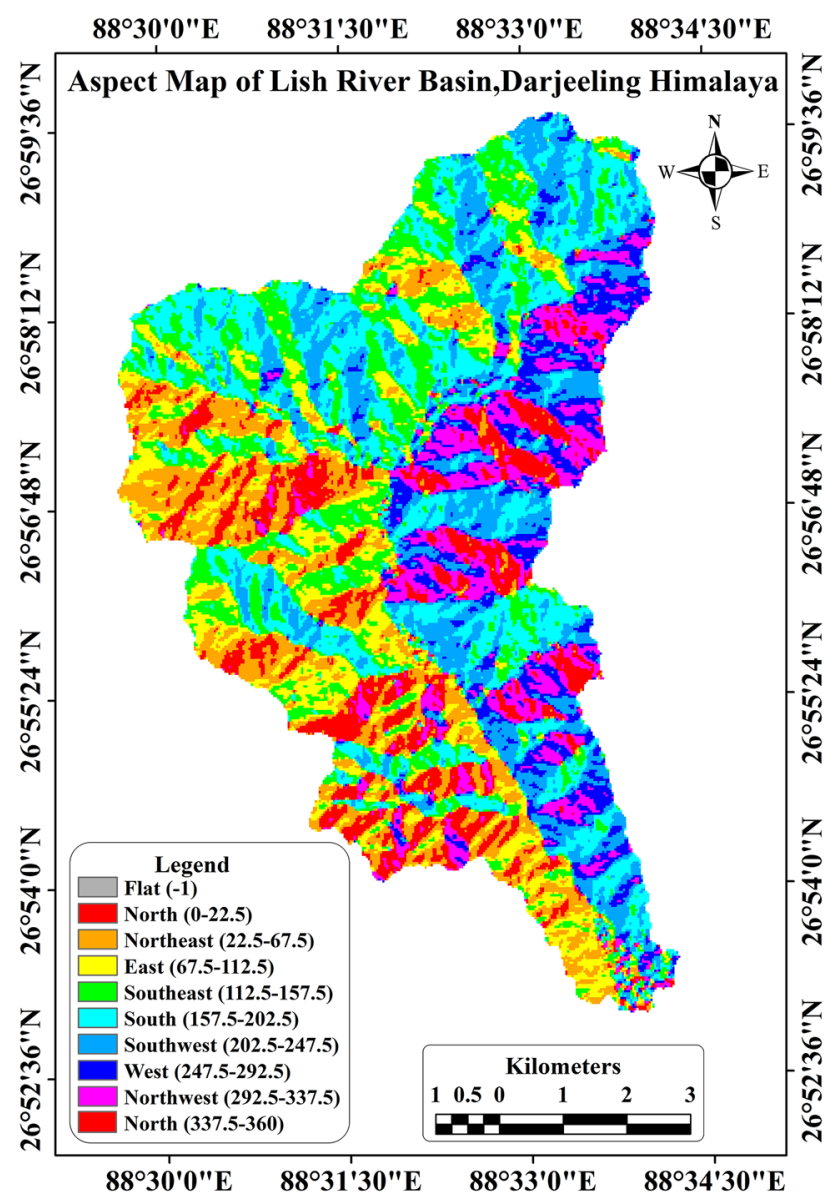

Fig. 5 Aspect map of the Lish River basin

\section{Application of frequency ratio model (FR) and landslide susceptibility}

Luzi et al. (2000), Lee and Choi (2003), Lee and Talib (2005), Porghasemi (2007), Lee and Pradhan (2007), Akgun et al. (2008), Jadda (2009), Pradhan and Lee (2009), Avinash and Ashamanjari (2010), Pradhan (2010a), Karim et al. (2011) and Intarawichian and Dasananda (2011) successfully applied 'FR' model to generate landslide susceptibility zoning map. To obtain frequency ratio $(F R)$ for each class of all the data layers a combination has been established between landslide inventory map and criterion maps using the following principle (Karim et al. 2011).

$\mathrm{Fr}_{\mathrm{i}}=\frac{\mathrm{N}_{\mathrm{pix}\left(\mathrm{S}_{\mathrm{i}}\right)} / \mathrm{N}_{\text {pix }\left(\mathrm{N}_{\mathrm{i}}\right)}}{\sum \mathrm{N}_{\mathrm{pix}\left(\mathrm{S}_{\mathrm{i}}\right)} / \sum \mathrm{N}_{\mathrm{pix}\left(\mathrm{N}_{\mathrm{i}}\right)}}$

where $\mathrm{N}_{\text {pix }\left(\mathrm{S}_{\mathrm{i}}\right)}$ the number of pixels containing slide in each class (i), $\mathrm{N}_{\mathrm{pix}\left(\mathrm{N}_{\mathrm{i}}\right)}$ total number of pixels having class (i) in the whole watershed. $\sum \mathrm{N}_{\mathrm{pix}\left(\mathrm{S}_{\mathrm{i}}\right)}$ total number of pixels containing landslide, $\sum \mathrm{N}_{\text {pix }\left(\mathrm{N}_{\mathrm{i}}\right)}$ total number of pixels in the whole area of the watershed. $8^{\circ} 30^{\prime} 0^{\prime \prime}$ E $\quad 8^{\circ} 31^{\prime} 30^{\prime \prime}$ E $\quad 8^{\circ} 33^{\prime} 0^{\prime \prime}$ E $\quad 8^{\circ} 34^{\prime} 30^{\prime \prime}$ E

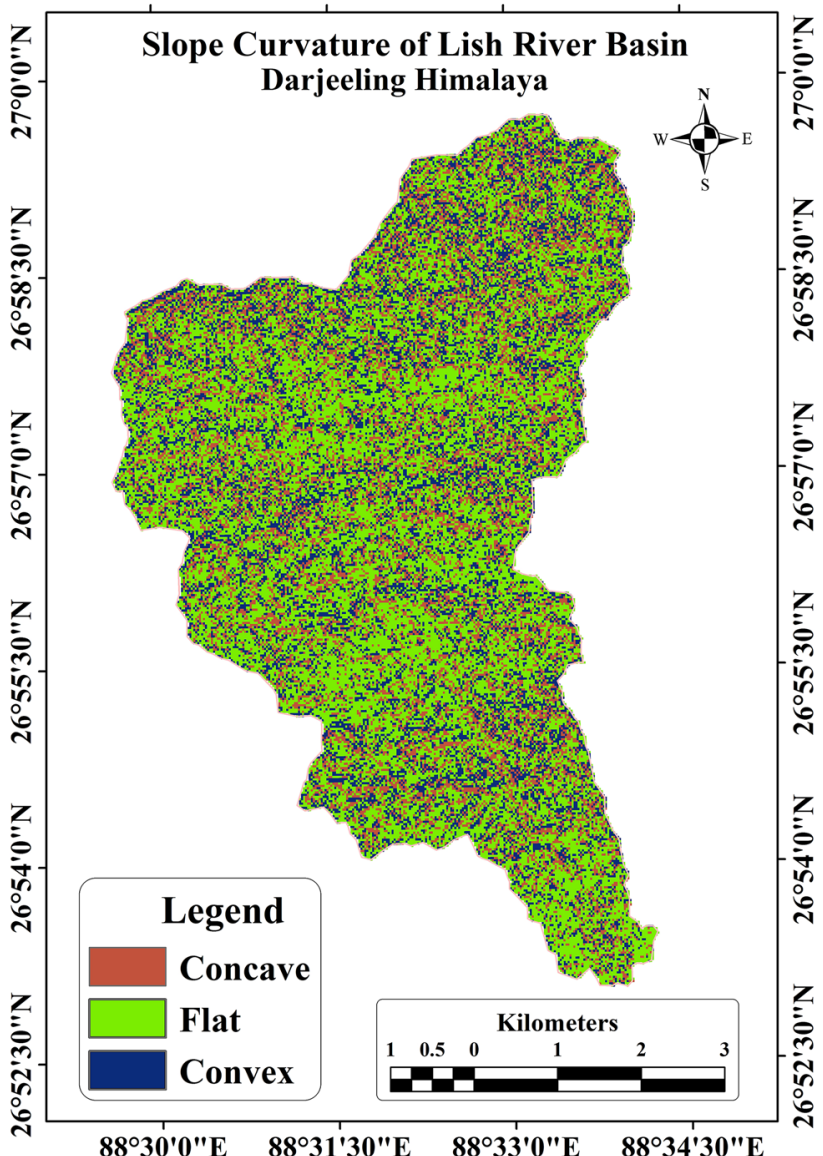

Fig. 6 Slope curvature of the Lish River basin

To obtain landslide susceptibility index (LSI), frequency ration of each range/class of all the landslide triggering factors were summed (Eq. 2) after

LSI $=\mathrm{Fr}_{1}+\mathrm{Fr}_{2}+\cdots+\mathrm{Fr}_{\mathrm{n}}$

where, LSI $=$ landslide susceptibility index; $\mathrm{Fr}=$ frequency ratio/rating to each class/range of landslide triggering factor.

\section{Result and discussion}

Slope angle, slope aspect and slope curvature and slope instability

Slope constitutes a very important parameter in landslide hazard zonation studies. A landslide potential index (LPI) is obtained for each terrain variable by calculating the ratio between the number of cells affected by landslides and the total number of cells for each specific class. The study shows that the LPI for the slope categories are increasing at a steady rate as the steepness increases and it 


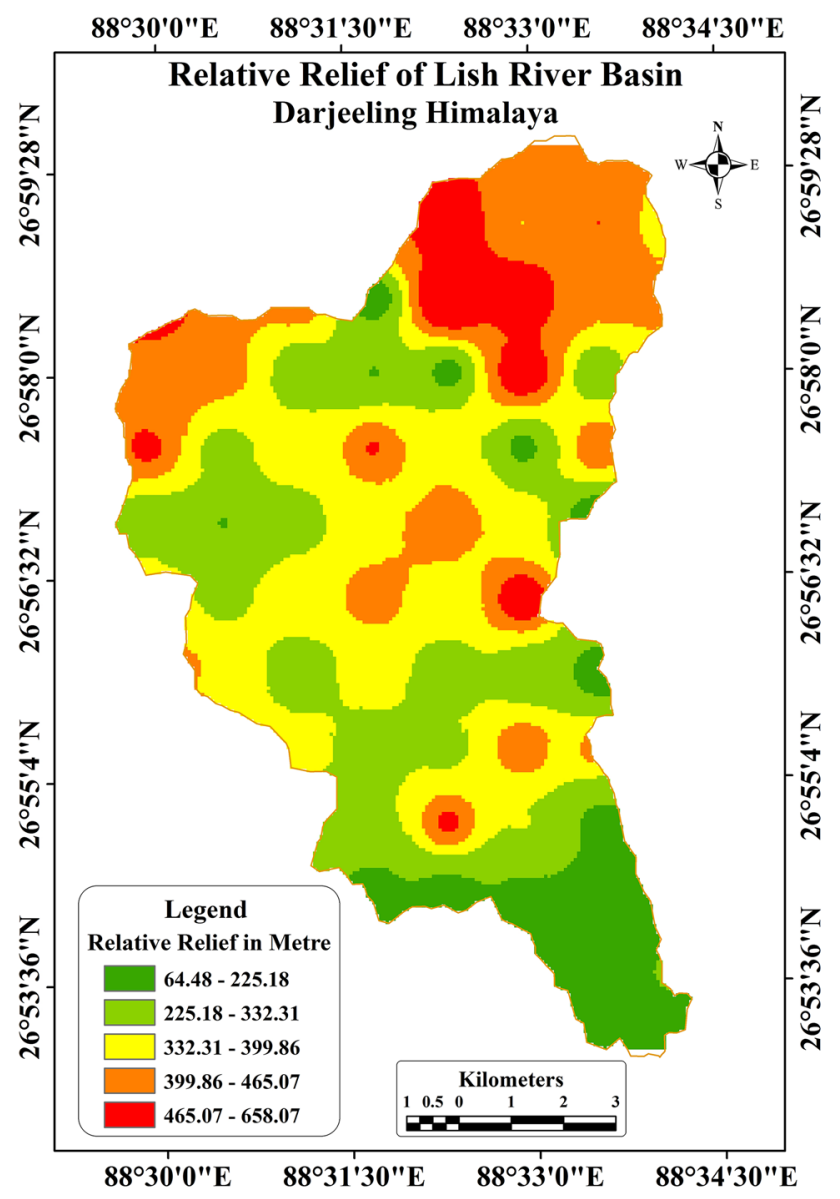

Fig. 7 Relative relief of the Lish River basin

is the indicator of the direct control of slope on the slope failure. All the cells having steepness $50-60^{\circ}$ and above are affected by landslide. In this study area, for these slope forming materials, the slope above $50^{\circ}$ can be considered as vulnerable and so care to be given to these areas (Fig. 4). There is a positive relationship between slope angle and frequency ratio which indicates higher slope angle is very much prone to slope failure in the Lish River basin (Table 2). In general the watershed shows the south, south east, and south west facing slope with some local variation due to the location of ridges, spurs and valleys. This slope aspect is helpful for the identification of slope segments which are required for the analysis of potentiality of slope failure. The varied direction of flow based on local slope and orientation of ridges, spurs and valleys shows the pattern of concentration of surface water and the places of potential surplus region. The prepared aspect map shows how much proportion of land in covered with varied slope direction (Fig. 5). In the Lish River basin the slope aspect of East, south east, south, west and North West revealed the high frequency ratio and high landslide

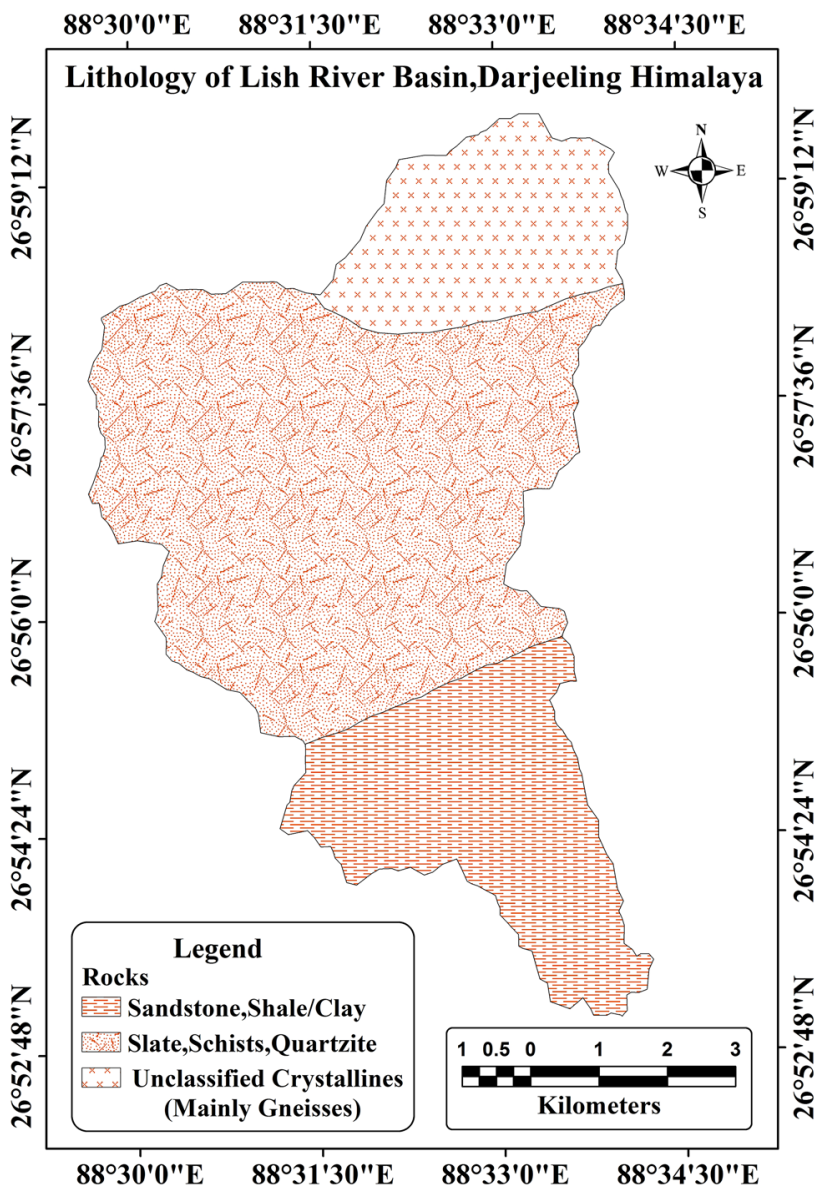

Fig. 8 Lithology of the Lish River basin

probability (Table 2). The curvature value represents the morphology of the topography. A positive curvature represents the surface is upwardly convex at the pixel and a negative curvature value represents the surface is upwardly concave at that pixel. A value ' 0 ' indicates that the surface is flat. The more positive and negative curvature value indicates the surface is more susceptible to landslide occurrences. It is assumed that high positive and high negative curvature of the slope provide a suitable condition for drainage concentration. Such drainage concentration over the space reduces the cohesion of the soil and induces slope failure. In the study area, the place of high positive and negative curvature area is experienced by high frequency ratio of 0.97 and 1.05 , respectively, and shows the greater probability of slope instability (Table 2). The curvature map shows very high negative and positive surface curvature in the north eastern and north western part of the Lish River basin (Fig. 6). The positive curvature is common and indicating the tendency of immediate drainage of surface water causing ready washing and so is detrimental to the stability of both soil and slope. 


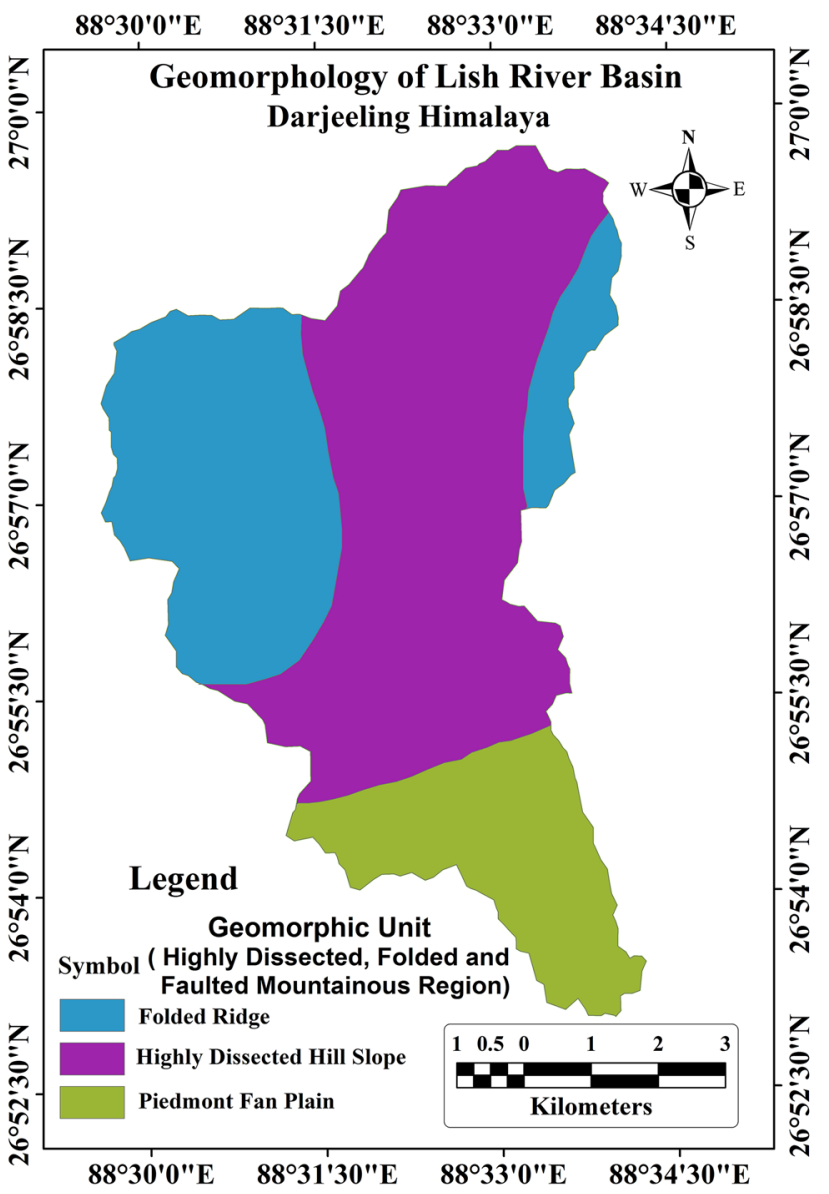

Fig. 9 Geomorphology of Lish River basin

\section{Relief, lithology and geomorphology}

The Relative relief of Lish River basin classified into five major categories and its value ranges from 64.48 to $680 \mathrm{~m}$. Extreme north eastern and north western sections are registered with maximum elevation and extreme southern part is characterised by lower relative relief (Fig. 7). Middle section and western part of the basin is dominated by moderate relative relief. The probability of landslide occurrences is very high beyond the relative relief of $300 \mathrm{~m}$. Landslide frequency ratio value is very high for moderate to moderately high relative relief (1.36 and 1.13) as well as high landslide probability in the Lish River basin (Table 2). Lihologically, the Lish River basin is classified into three categories such as sandstone shale/clay; slate, schist, quartzite and unclassified, crystallines (mainly gneisses). Middle section of the basin is characterised by the existence of slate, schist and quartzite (Fig. 8). The extreme south of the basin is registered with very fragile lithology that is sandstone, shale and clay. On the other land the extreme northern part is covered by unclassified, crystallines rock mainly Gneisses (Fig. 8). In term of areal

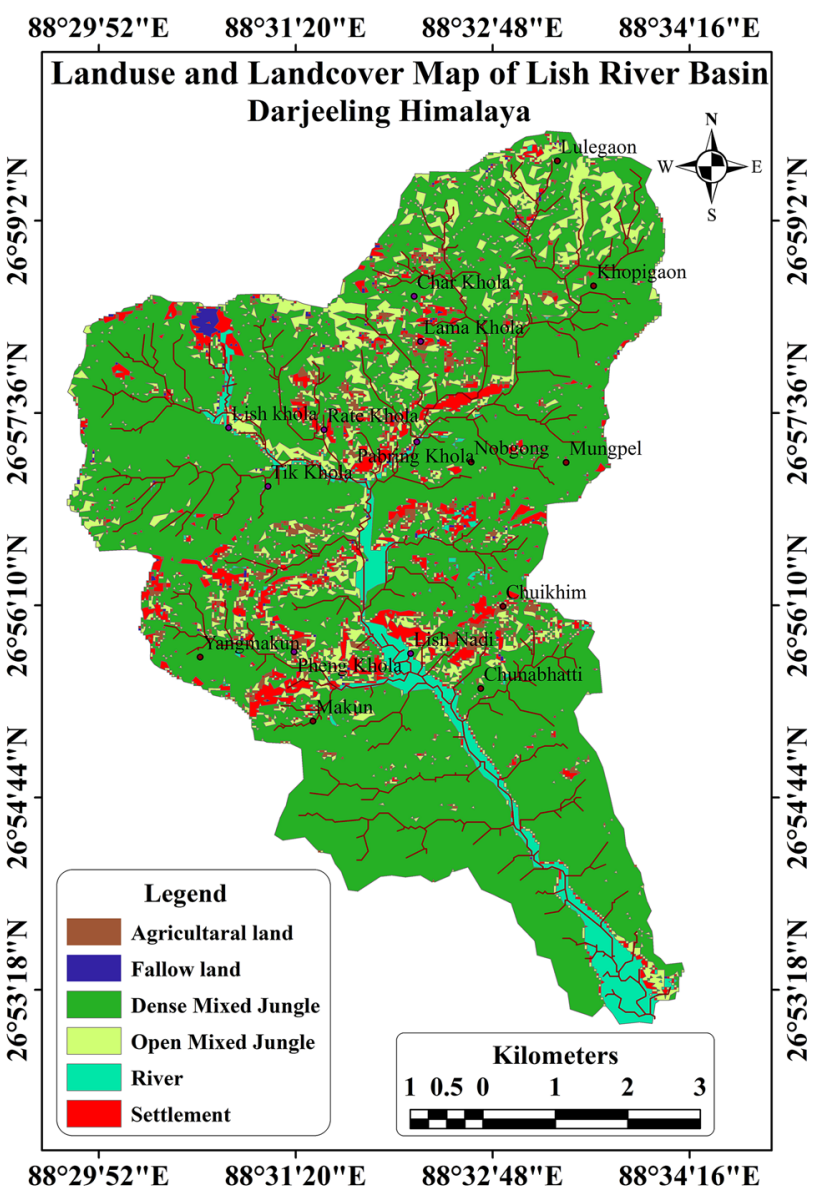

Fig. 10 Land use/cover map of Lish River basin

coverage the rock groups of slate, schist and quartzite rank first and which is followed by unclassified, crystallines rocks and sandstone shale/clay. The upper part of the basin appeared slightly high landslide prone zone compared with the lower part of the basin. The lithological composition of Sandstone Shale/Clay, Slate, Schists, quartzite and Unclassified, Crystallines are characterized by the frequency ratio value of $0.30,1.43$ and 0.47 (Table 2). Geomorphologically, the Lish River basin is divided into three categories such as folded ridge, highly dissected hill slope and piedmont fan plain (Fig. 9). Most of the area, basically whole middle part of the basin which characterised by highly dissected hill slope. The eastern and western part of this basin is characterised by folded ridge and the extreme southern part of this basin is covered by piedmont fan plain. The lower portion of this basin is covered by piedmont fan plain and existence of piedmont fan plain and low elevation where landslide occurrences are very low. The probability of landslide events is high in folded geomorphology. The frequency ratio (FR) of folded ridges, dissected hills and piedmont plain are 1.96, 0.72 and 0.10, respectively (Table 2 ). 
Table 3 Soil characteristics of Lish River basin

\begin{tabular}{llcl}
\hline $\begin{array}{l}\text { Map } \\
\text { symbol }\end{array}$ & Characteristics & Taxonomic name & $\begin{array}{c}\text { Area, 000 ha } \\
(\%)\end{array}$ \\
\hline W002 & $\begin{array}{l}\text { Moderately shallow excessively drained coarse loamy soils occurring on } \\
\text { steep side slopes with gravelly loamy surface, severe erosion and strong } \\
\text { rockiness. Associated with moderately shallow, well drained, gravely } \\
\text { loamy soils with loamy surface and moderate erosion } \\
\text { Moderately shallow well drained, gravelly loamy soils occurring on steep } \\
\text { side slopes with gravelly loamy surface, moderate erosion and moderate } \\
\text { rockiness. Associated with moderately shallow, somewhat excessively } \\
\text { drained, gravelly loamy soils with loamy surface, moderate erosion and } \\
\text { moderate rockiness }\end{array}$ & $\begin{array}{c}\text { Loamy skeletal, typic haplumbrepts. } \\
\text { Loamy skeletal, typic udorthents }\end{array}$ & 40.9 $(0.46 \%)$ \\
W008 & $\begin{array}{l}\text { Very deep poorly drained, coarse loamy soils occurring on level to nearly } \\
\text { level lower pied, most plain loamy surface. Associated with very deep, } \\
\text { poorly, drained, coarse loamy soils }\end{array}$ & $\begin{array}{c}\text { Coarse loamy, typic haplaquents. } \\
\text { Coarse loamy, typic fluvaquents }\end{array}$ \\
\hline
\end{tabular}

88²9'52"E $\quad 88^{\circ} 31^{\prime} 20^{\prime \prime} E \quad 88^{\circ} 32^{\prime} 48^{\prime \prime} \mathrm{E} \quad 88^{\circ} 34^{\prime} 16^{\prime \prime} \mathrm{E}$

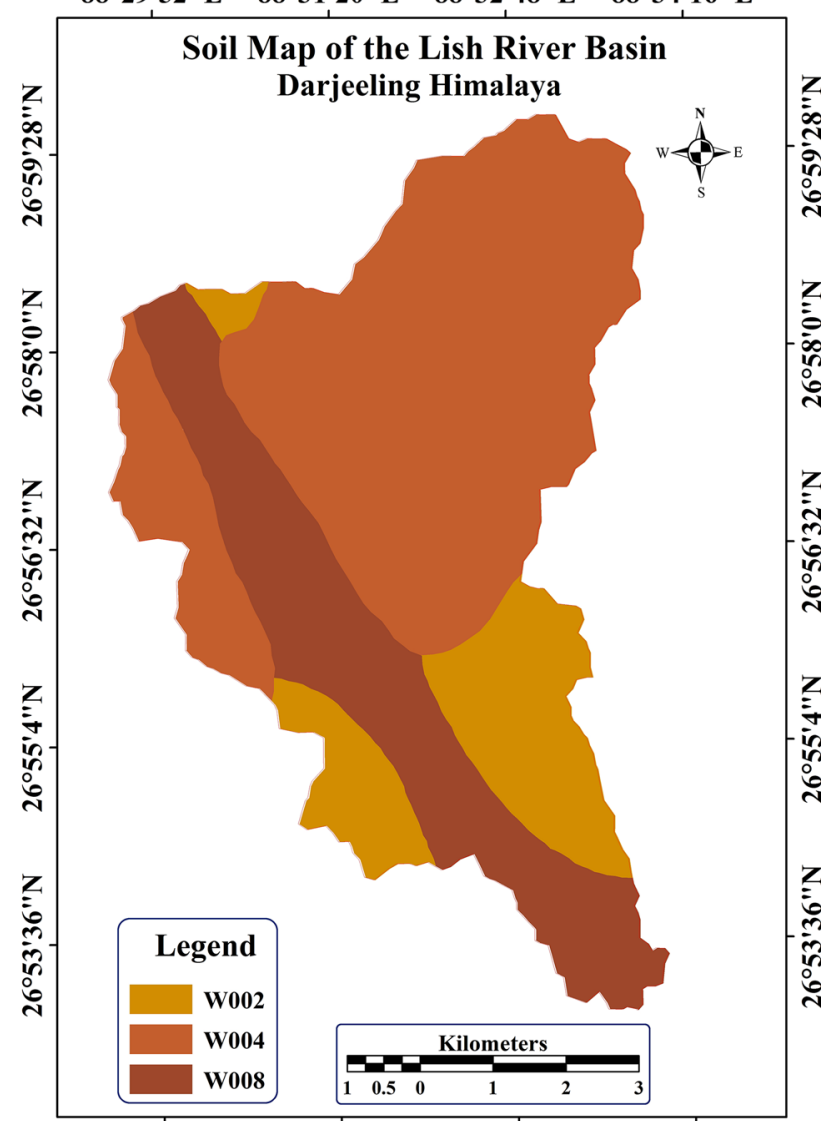

$88^{\circ} 29^{\prime} 52^{\prime \prime} \mathrm{E} \quad 88^{\circ} 31^{\prime} 20^{\prime \prime} \mathrm{E} \quad 88^{\circ} 32^{\prime} 48^{\prime \prime} \mathrm{E} \quad 8^{\circ} 34^{\prime} 16^{\prime \prime} \mathrm{E}$

Fig. 11 Soil map of the Lish River basin

\section{Land use/land cover characteristics}

The land use/land cover map was classified into agricultural land, fallow land, dense mixed jungle, open mixed jungle, river and settlement (Fig. 10). More than

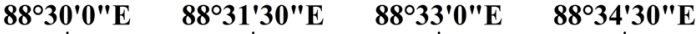

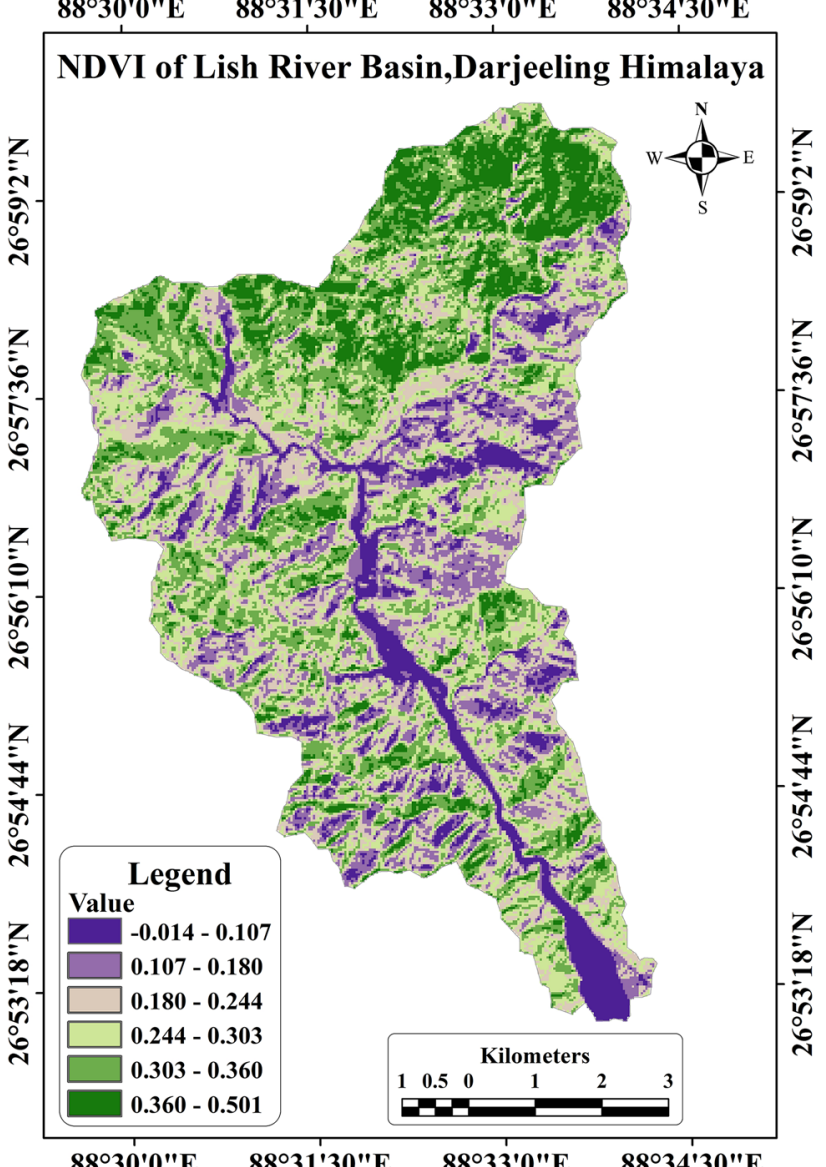

Fig. 12 NDVI status of the Lish River basin

$70 \%$ area of this basin registered with dense mixed jungle followed by open mixed jungle $(11 \%)$, settlement, river, agriculture land, follow land. The Frequency ratio of the settlement area is 1.81 which denotes the higher probability of landslides. The frequency ratio of 


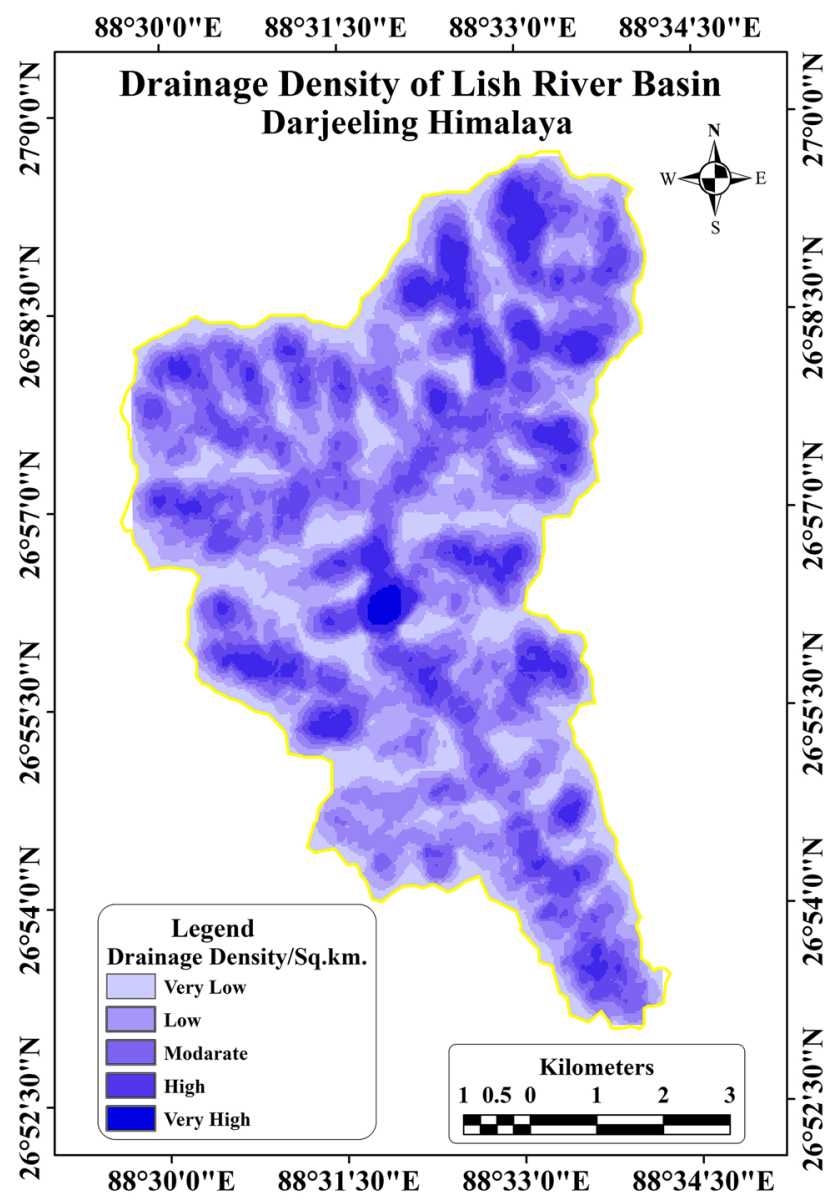

Fig. 13 Drainage density map of Lish River basin

agriculture land (0.9), fallow land (0.61), and open mixed jungle (0.74) are less than 1 and expected as low probability of landslide phenomena.

\section{Soil and landslide probability}

Soil of the Lish River basin is classified into three categories such as W002, W004 and W008 which are further sub-divided into six classes (Table 3). Maximum area of the basin is covered with moderately shallow well drained, gravelly loamy soils occurring on steep side slopes with gravelly loamy surface, moderate erosion and moderate rockiness which is also associated with moderately shallow, somewhat excessively drained, gravelly loamy soils with loamy surface, moderate erosion and moderate rockiness (Fig. 11). This type of the soil shows the large number of landslide phenomena. The soil taxonomic class of W002 and W004 are associated with high frequency ratio (1.28 and 0.81$)$ and higher probability of landslide phenomena in the Lish River basin of the Eastern Himalaya (Table 2).

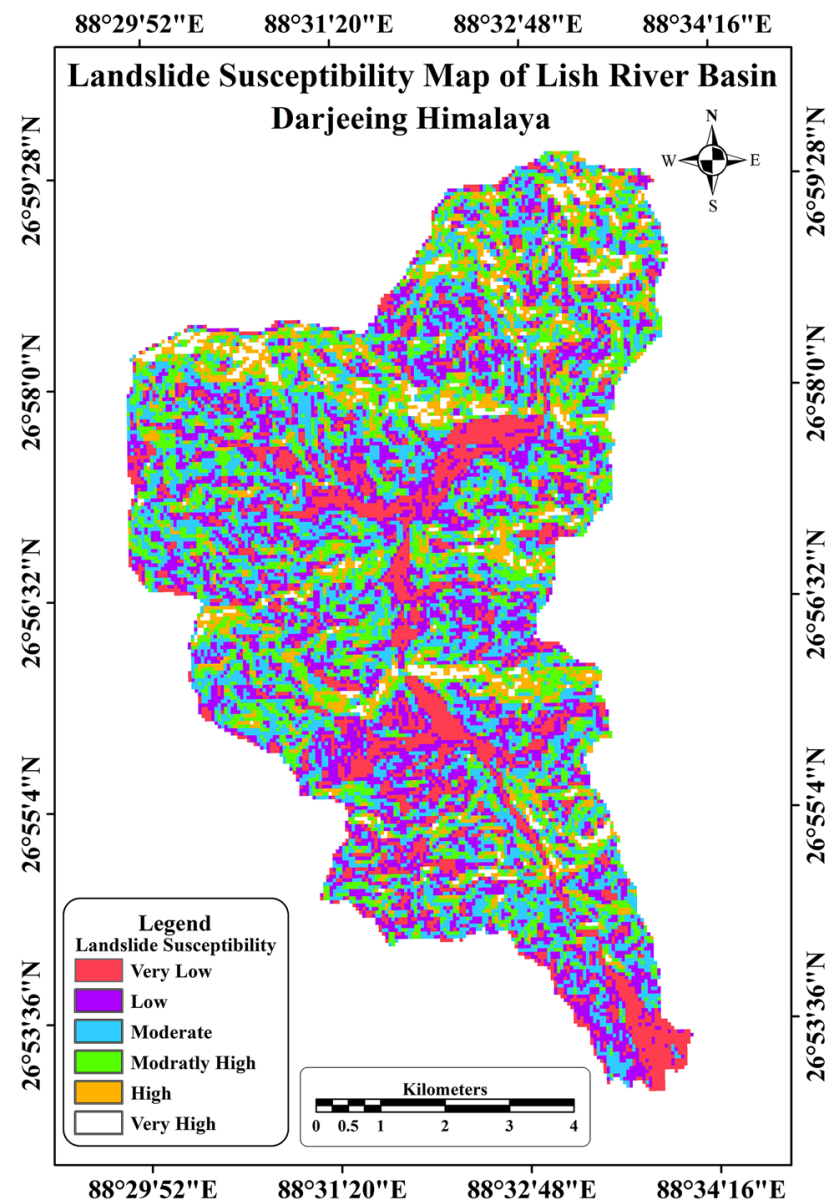

Fig. 14 Landslide susceptibility map of the Lish River basin

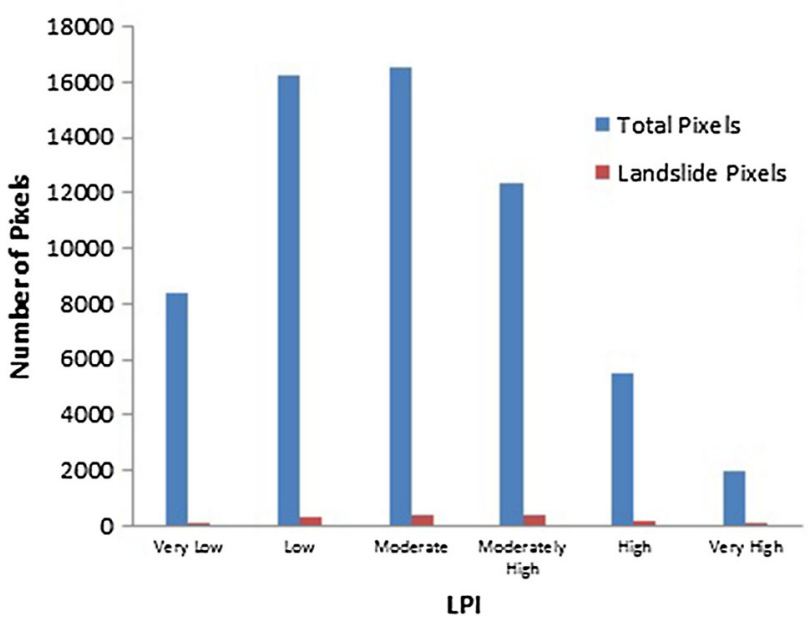

Fig. 15 Areal coverage of landslide potential index

\section{NDVI and slope instability}

Normalised differential vegetation index (NDVI) reflects the status of vegetation health as well as soil moisture 


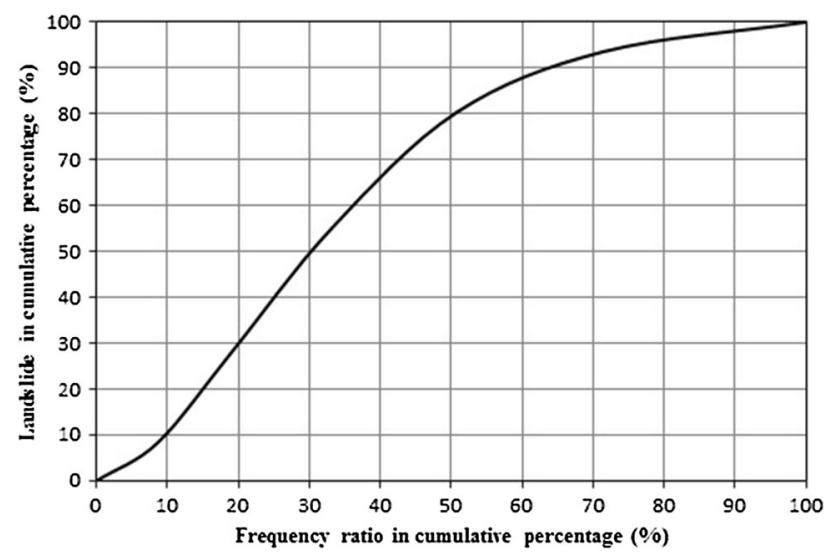

Fig. 16 Success rate curve

condition over the space. In the Lish River basin (Fig. 12), the area on both sides of the major tributary revealed the less vegetation where the slope is exposed to rainfall, surface run-off and finally soil erosion and slope instability. The value of NDVI ranges from 0 to 1 . Near to 1 means better quality and near to 0 means low quality. It is mainly used to judge the vegetation quality. The frequency ratio is very high for negative NDVI value which depicts that the slopes with less vegetation cover exposed to atmospheric process and make the slope more susceptible to slope instability (Table 2). In the study area the NDVI value ranges from 0.83 to 1.16 .

\section{Drainage density and landslide probability}

Drainage density is the total length of all the streams and rivers in a drainage basin divided by the total area of the drainage basin. It is a measure of how well or how poorly a watershed is drained by stream to length of overland flow. Rugged regions or those with high relief will also have a higher drainage density than other drainage basins if the other characteristics of the basin are the same. Drainage density can affect the shape of a river's hydrograph during a rain storm. Rivers that have a high drainage density will often have a more 'flashy' hydrograph with a steep falling limb. High densities can also indicate a greater flood risk.
High drainage densities also mean a high bifurcation ratio. The area covered with high and very high drainage density is revealed with the frequency ratio of 1.31 and 1.19, respectively, which indicate higher probability of landslide (Fig. 13). On the other hand low drainage density having the less frequency ration and also showed the less landslide probability.

\section{Landslide susceptibility zonation map}

Landslide Susceptibility map of the Lish River basin is classified into 6 categories such as very low, low, moderate, moderately high, high and very high. The study revealed that there is a positive relationship between landslide susceptibility and frequency ratio. Lower the frequency ratio value means, the low probability of landslide. On the other hand higher the frequency ratio value, grater the probability of landslide. Maximum landslide occurs in moderate $(26.72 \%)$ to moderately high $(25.30 \%)$ landslide susceptibility classes covering near about $52 \%$ of the total landslides affected area (Fig. 14). So the Lish River is moderately high landslide prone basin. The Lish River basin is dominated by moderate landslide susceptibility which is followed by moderately high, low, high, very low and very high (Fig. 15). The derived success rate curve revealed that more than $60 \%$ area is under moderate to moderately high landslide susceptibility (Fig. 16; Table 4).

\section{Conclusion}

Landslide in the mountain environment of Eastern Darjeeling Himalaya is one of the most significant natural hazards which sometimes cause great damage to human lives and properties. To minimize the damage caused due to landslides, the identification of potential landslide zones is of utmost important. In the present study, the application of frequency ratio model and preparation of landslide susceptible zones will provide a great support to planner and policy makers for ensuring further developmental activities in the Lish River basin. The relationship between

Table 4 Landslide susceptibility and frequency ratio

\begin{tabular}{llllcc}
\hline Landslide susceptibility & Total pixels & \% of total pixels & Landslides pixel & \% of landslides pixel & Frequency ratio \\
\hline Very low & 8363 & 13.72 & 126 & 8.50 & 0.62 \\
Low & 16,269 & 26.69 & 294 & 19.84 & 0.74 \\
Moderate & 16,531 & 27.12 & 396 & 26.72 & 0.99 \\
Moderately high & 12,363 & 20.28 & 375 & 25.30 & 1.25 \\
High & 5490 & 9.01 & 196 & 13.23 & 1.47 \\
Very high & 1938 & 3.18 & 95 & 6.41 & 2.02 \\
\hline
\end{tabular}


all the factors map, landslide inventory map and landslide susceptibility map of the Lish River basin revealed that steep slope segment, moderate to high drainage density, high positive and high negative slope curvature, fragile lithology, south-south east and south west facing slope, and settlement area are attributed with high frequency ration and high landslide susceptibility. Mountain slope segment having all these characteristics are to be avoided for further construction for development so that future environmental hazards and disasters can be arrested.

\section{References}

Ahmed MF, Rogers JD, Ismail EH (2014) A regional level preliminary landslide susceptibility study of the upper Indus river basin. Eur J Remote Sens 47:343-373

Akgun A, Dag S, Bulut F (2008) Landslide susceptibility mapping for a landslide-prone area (Findikli, NE of Turkey) by likelihood frequency ratio and weighted linear combination models. Environ Geol 54(6):1127-1143

Anbalagan R (1992) Landslide hazard evaluation and zonation mapping in mountainous terrain. Eng Geol 32:269-277

Atkinson PM, Massari R (1998) Generalized linear modeling of susceptibility to landsliding in the central Apennines, Italy. Comput Geosci 24:373-385

Avinash KG, Ashamanjari KG (2010) A GIS and frequency ratio based landslide susceptibility mapping: Aghnashini river catchment, Uttara Kannada, India. Int J Geomat Geosci 1(3):343-354

Bagherzadeh A, Mansouri Daneshvar MR (2012) Mapping of landslide hazard zonation using GIS at Golestan watershed, northeast of Iran. Arab J Geosci 6:3377-3388

Basu SR, Ghatowar L (1990) The impact of landslides on fluvial processes in the Lish basin of the Darjeeling Himalayas. Geogr Pol 59:77-87

Borga et al (1998) Shallow landslide hazard assessment using a physically based model and digital elevation data. J Environ Geol 35(2-3):81-88

Bui DT, Pradhan B, Lofman O, Revhaug I, Dick OB (2012) Landslide susceptibility mapping at Hoa Binh province (Vietnam) using an adaptive Neuro-fuzzy inference system and GIS. Comput Geosci 45:99-211

Caiyan WU, Jianping Q (2009) Relationship between landslides and lithology in the Three Gorges Reservoir area based on GIS and information value model. Front For China 4:165-170. doi:10. 1007/s11461-009-0030-6

Dhakal AS, Amada T, Aniya M (2000) Landslide hazard mapping and its evaluation using GIS: an investigation of sampling schemes for a grid-cell based quantitative method. Photogramm Eng Remote Sens 66(8):981-989

Donati L, Turrini MC (2002) An objective and method to rank the importance of the factors predisposing to landslides with the GIS methodology, application to an area of the Apennines (Valnerina; Perugia, Italy). Eng Geol 63(3-4):277-289

Einstein HH (1988) Special lecture, landslide risk assessment. In: Proceedings of 5th international symposium on landslides, Lausanne, Balkema, Rotterdam, The Netherlands, pp 1075-1090

Erener A, Uzgeun HSBD (2008) Analysis on landslide hazard mapping methods: regression models versus weight rating. In: The international archives of the photogrammetry, remote sensing and spatial sciences, vol. 37 (Part B8), Beijing
Ghorai D, Maiti S, Paul AK (2015) Landslide susceptibility mapping: a case study of Cauvery basin and east flowing rivers south of Cauvery basin, India. J Remote Sens GIS 6(1):24-36

Gokceoglu C, Sonmez H, Ercanoglu M (2000) Discontinuity controlled probabilistic slope failure risk map of the Altindag (settlement) region in Turkey. Eng Geol 55:277-296

Guzzetti F, Carrara A, Cardinali M, Reichenbach P (1999) Landslide hazard evaluation: a review of current techniques and their application in a multi-scale study, Central Italy. J Geomorphol 31:181-216 (Elsevier, London)

Ilanloo M (2011) A comparative study of fuzzy logic approach for landslide susceptibility mapping using GIS: an experience of Karaj dam basin in Iran. Procedia Soc Behav Sci 19:668-676

Intarawichian N, Dasananda S (2011) Frequency Ratio model based landslide susceptibility mapping in lower Mae Chaem watershed, northern Thailand. Environ Earth Sci 64:2271-2285

Jadda M (2009) Landslide susceptibility evaluation and factor effect analysis using probabilistic-frequency ratio model. Eur J Sci Res 33(4):654-668

Jibson WR, Edwin LH, John AM (2000) A method for producing digital probabilistic seismic landslide hazard maps. Eng Geol 58:271-289

Kamp U, Growley BJ, Khattak GA, Owen LA (2008) GIS based landslide susceptibility mapping for the 2005 Kashmir earthquake region. Geomorphology 101:631-642

Komac M (2006) A landslide susceptibility model using the analytical hierarchy process method and multivariate statistics in pei alpine Slovenia. Geomorphology 74:17-28

Karim S, Jalileddin S, Ali MT (2011) Zoning landslide by use of frequency ratio method (case study: Deylaman Region). MiddleEast J Sci Res 9(5):578-583

Lee S (2004) Application of likelihood ratio and logistic regression models to landslide susceptibility mapping using GIS. Environ Manag 34(2):223-232

Lee S, Choi U (2003) Development of GIS-based geological hazard information system and its application for landslide analysis in Korea. Geosci J 7:243-252

Lee S, Pradhan B (2006) Landslide hazard assessment at Cameron Highland Malaysia using frequency ratio and logistic regression models. Geophys Res Abstr 8: (SRef ID: 1607-7962/gra/ EGU06-A-03241)

Lee S, Pradhan B (2007) Landslide hazard mapping at Selangor, Malaysia using frequency ratio and logistic regression models. Landslides 4(1):33-41

Lee S, Sambath T (2006) Landslide susceptibility mapping in the Damrei Romel area, Cambodia using frequency ratio and logistic regression models. Environ Geol 50:847-855

Lee S, Talib JA (2005) Probabilistic landslide susceptibility and factor effect analysis. Environ Geol 47:982-990

Lee S, Ryu JH, Min K, Won JS (2003) Landslide susceptibility analysis using artificial neural network at Boun, Korea. Environ Geo 44:820-833

Lee S, Choi J, Min K (2004) Probabilistic landslide hazard mapping using GIS and remote sensing data at Boun, Korea. Int J Remote Sens 25:2037-2052

Lee MJ, Choi JW, Oh HJ, Won JS, Park I, Lee S (2012) Ensemblebased landslide susceptibility maps in Jinbu area. Environ Earth Sci 67(1):23-37. doi:10.1007/s12665-011-1477-y

Luzi L, Pergalani F, Terlien MTJ (2000) Slope vulnerability to earthquake at subregional scale, using probabilistic techniques and geographic information systems. Eng Geol 58:313-336

Mandal S, Maiti R (2011) Landslide susceptibility analysis of Shivkhola Watershed, Darjeeling: a remote sensing \& GIS Based analytical hierarchy process (AHP). J Indian Soc Remote Sens. doi:10.10007/s12524-011-0160-9 
Muthu K, Petrou M (2007) Landslide hazard mapping using an ExpertSystem and a GIS. Trans Geosci Remote Sens 45(2):522-531

Nithya ES, Prasanna RP (2010) An integrated approach with GIS and remote sensing technique for landslide zonation. Int J Geomat Geosc 1(1):66-75

Pradhan B (2010a) Remote sensing and GIS-based landslide hazard analysis and crossvalidation using multivariate logistic regression model on three test areas in Malaysia. Adv Space Res 45:1244-1256

Pradhan B (2010b) Use of GIS-based fuzzy logic relations and its cross application to produce landslide susceptibility maps in three test areas in Malaysia. Environ Earth Sci. doi:10.1007/ s12665-010-0705-1

Pradhan B (2010c) Manifestation of an advanced fuzzy logic model coupled with Geoinformation techniques to landslide susceptibility mapping and their comparison with logistic regression modelling. Environ Ecol Stat. doi:10.1007/s10651010-0147-7

Pandey A, Dabral PP, Chowdhary VM, Yadav NK (2008) Landslide hazard zonation using remote sensing and GIS: a case study of Dikrong river basin, Arunachal Pradesh, India. Environ Geol 54:1517-1529

Pardeshi SD, Autade SE, Pardeshi SS (2013) Landslide hazard assessment: recent trends and techniques. Springer Plus 2:1-11. doi:10.1186/2193-1801-2-523

Pistocchi A, Luzi L, Napolitano P (2002) The use of predictive modeling techniques for optimal exploitation of spatial databases: a case study in landslide hazard mapping with expert system-like methods. Environ Geol 41:765-775

Porghasemi H (2007) Landslide hazard zoning statistical frequency ratio method in the basin Safarood, MSc thesis, Tarbiat Modarres University, Noor, p 1386

Poudyal CP, Chang C, Oh HJ, Lee S (2010) Landslide susceptibility maps comparing frequency ratio and artificial neural networks: a case study from the Nepal Himalaya. Environ Earth Sci 61:1049-1064
Pourghasemi HR, Pradhan B, Gokceoglu C, Deylami Moezzi K (2012) A comparative assessment of prediction capabilities of Dempster-Shafer and Weights-of-evidence models in landslide susceptibility mapping using GIS. Geomat Nat Hazards Risk. doi:10.1080/19475705.2012.662915

Pradhan B, Lee S (2009) Landslide risk analysis using artificial neural network model focusing on different training sites. Int J Phys Sci $4: 1-15$

Pradhan B, Lee S (2010) Landslide susceptibility assessment and factor effect analysis: back propapagation artificial neural netorks and their comparison with frequency ratio and bivariate logistic regression modelling. Environ Model Softw 25:747-759

Pradhan B, Lee S, Buchroithner MF (2010) A GIS-based backpropagation neural network model and its cross application and validation for landslide susceptibility analyses. Comput Environ Urban Syst. doi:10.1016/j.compenvurbsys.2009.12.004

Rowbotham D, Dudycha DN (1998) GIS modelling of slope stability in Phewa Tal Watershed, Nepal. Geomorphology 26:151-170

Sarkar S, Kanungo DP (2004) An integrated approach for landslide susceptibility mapping using remote sensing and GIS. Photogramm Eng Remote Sens 70(5):617-625

Sarkar S, Kanungo D, Mehrotra G (1995) Landslide hazard zonation: a case study of Garhwal Himalaya, India. Mt Res Dev 15:301-309

Tsai F, Lai JS, Chen WW, Lin TH (2013) Topographic and vegetative factors of data mining for landslide verification and risk assessment. Ecol Eng 61:669-677

Varnes D, IAEG (1984) Landslide hazard zonation: a review of principle and practice. UNESCO, Paris, pp 1-6

Yalcin A (2008) GIS-based landslide susceptibility mapping using analytical hierarchy process and bivariate statistics in Ardesen (Turkey): comparisons of results and confirmations. Catena 72:1-12

Zhou CH, Lee CF, Li J, Xu ZW (2002) On the spatial relationship between landslide and causative factors on Lantau Island, Hong Kong. Geomorphology 43:197-207 